\title{
Death by Stoning in the Hebrew Bible and in Post- Biblical Traditions
}

\author{
SHAUl Bar (UNIVERSity OF MEMPHIS)
}

\begin{abstract}
Different modes of death appear in the Hebrew Bible, among which we find stoning as a form of execution. Since the person is dead, why does the Bible go to such lengths to describe this manner of death? In order to proffer an answer, we shall examine the cases which describe death by stoning. The intention behind stoning seems to have been to remove the criminal from the camp and the city. This was not merely a physical removal; it also bore significance for the dead man's spirit. The punishment of stoning prevented the burial of the corpse. Nonburial was worse than death because the spirit of the dead would not find rest and would therefore never reach the underworld. In a later period, the procedure for stoning was modified. Forms of judicial execution mentioned in the Bible, compared with those in the Talmud, indicate the latter made an effort to preserve the body of an executed man. This difference stems from the fact that in the Talmudic period the idea of resurrection was well developed.
\end{abstract}

KEYWORDS: Stoning, Idolatry, Blaspheme, Divination, Adultery, Defiant son, Adulterous woman, Betrothed virgin, Non-burial.

\section{A INTRODUCTION}

Of the various forms of death that appear in the Hebrew Bible, natural death is the most common. However, there are also various modes of unnatural deathpremature death in war, by judicial execution (stoning, impaling, burning, decapitation strangulation) or by excision, plague or illness. The Talmudic sages counted 903 different types of death. The worst of them, they said, is death from asthma or croup; the easiest, death by Divine kiss, which is the lot of the righteous and is compared to removing a hair from milk. ${ }^{1}$ Great importance was assigned to the manner and the day of a person's death because these were indicators of whether the deceased was good or bad. ${ }^{2}$ The age of the deceased is also significant - death before age 50 was considered to be 'excision, extirpation' (Lev 18:29), death at age 60, a ripe age, at 70, old age and 80,

\footnotetext{
Submitted: 30/03/2021; peer-reviewed: 26/11/2021; accepted: 06/12/2021. Shaul Bar, "Death by Stoning in the Hebrew Bible and in Post-biblical Traditions," Old Testament Essays 34 no. 3 (2021): 789 - 805. DOI: https://doi.org/10.17159/23123621/2021/v34n3a8.

1 b. Berakhot. 8a; b. Baba Bathra. 17a.

2 b. Mo'ed Qatan. 28 .
} 
advanced age. ${ }^{3}$ Texts from the ancient Near East rarely describe how the condemned were put to death. For example, when the Code of Hammurabi, prescribes death for those who commit a particular crime, the method of execution is not specified, ${ }^{4}$ except in a few cases that stipulate drowning, ${ }^{5}$ burning, etcetera. ${ }^{6}$ The Bible, too, generally employs the laconic מוֹת mot yumat 'he shall be put to death.' We have definite knowledge of only two forms of execution-stoning (after which the corpse was suspended in public view) and burning. This essay will explore the subject of stoning - the different cases of stoning and the circumstances under which this mode of execution was practiced. What was the reason for describing this mode of death and how different was it from other descriptions of death in the Hebrew Bible? In addition, we will describe the procedure for stoning and who carried it out. In a later period, the procedure for stoning was modified, as we find in the Mishnah. Thus, what was the reason for this change? We will use the synchronic method of analysing the biblical text as it stands. I will review material found in the Talmud and the Jewish medieval commentaries which are less noted in the main scholarly works. Almost everything that Jews were taught during a period of more than thousand years can be found there. This scrutiny of the post-biblical tradition will reveal that the people made an effort to preserve the body of an executed man. This difference from the biblical text may stem from the fact that in Talmudic times the idea of resurrection was well developed and points to historical development.

\section{B STONING (סְקִילָּה) FOR VIOLATIONS OF DIVINE LAW}

The transgressions punishable by stoning are in the domain of human relations with God. Persons liable to this penalty includes those who seduce their fellows to idolatry (Deut 13:11), those who actually engage in idolatry (Deut 17:5), those who employ the Divine name in a curse (Lev 24:16), those who offer their children to Molech (Lev 20:2), the medium and necromancer (Lev 20:27) anda specific case with which we begin - the man who gathered wood on the Sabbath (Num 15:32-36).

That a ị is one who gathers something can be inferred from "let them

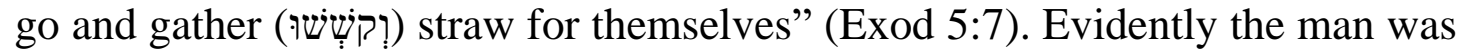
warned about the consequences of his action, since otherwise he would not have been subject to capital punishment prescribed by a human court. The wood gatherer was brought before the elders, who sat in judgment with Moses and Aaron, after which he was kept under guard until his trial. His sentence was

3 Ibid.

4 "The Code of Hammurabi" (trans. Theophile J. Meek; ANET no.1-3, 6-11, 14-16, 19, 22, 26, 33, 109, 116, 130, 210, 229, 230), 166-176.

5 Ibid., no. 108, 129, 143, 170-172.

$6 \quad$ Ibid., pp.167, 170, 172, 177. $\S \S n o .25,110,157$; he was tied to bulls which dragged him through the field $(\$ 256)$. 
known in advance_- "whoever does work on the Sabbath day shall be put to death" (Exod 31:15) — but the form of execution was never stated. Only in the wake of this man's action was stoning prescribed as the punishment for public desecration of the Sabbath (Num15:35). Some believe that this penalty was applied to all Sabbath desecrators - a view reinforced by the Talmud: "It once happened that a man rode a horse on the Sabbath in the Greek period and he was brought before the Court and stoned."7 The rabbis believed that the wood gatherer merited capital punishment. However, Moses was not sure about the mode of execution. "Our master Moses knew that the wood gatherer [had incurred the penalty of ] death as it said, 'He who desecrates it shall be put to death' (Exod 31:14) but he did not specify by what mode of execution he should be killed." 9 Therefore he consulted the divine oracle and the answer was "death by stoning." 10 It is not clear if the wood gatherer's action is a violation of the commandment about resting on the Sabbath. ${ }^{11}$ However, the gathering of the wood had one purpose; to use it for lighting fire, which, according to Exod 35:3, is forbidden on the Sabbath day. ${ }^{12}$ Phillips sees the story as an extension of the Sabbath ethics to all forms of domestic activity. ${ }^{13}$

Stoning is also specified when a brother, child, wife or friend attempts to seduce a person to idolatry (Deut 13:7 [6]). A person like that merits neither mercy nor pity. He must be stoned to death-struck down first by his intended victim, followed by the rest of the people (13:10 [9]). The text says "stone him that he die" (Deut 13:11 [10]) because a barrage of stones is not necessarily fatal (see 2 Sam 16:6); hence, the appended "that he die (וְֶֶ)," to require that the stoning continue until the condemned man is dead. The Masoretic Text of verse

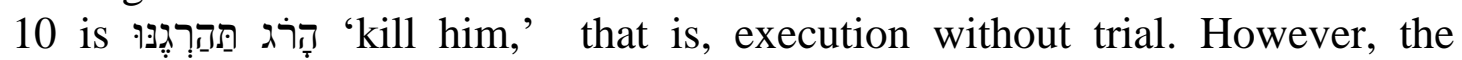

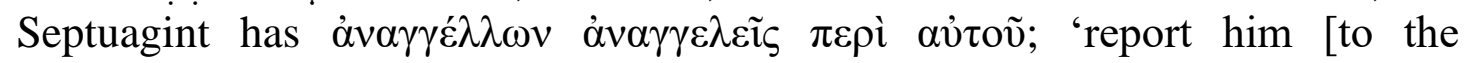
authorities],' evidently reflecting a Hebrew text (Lev 5:1; Josh 2:14, 20; Jer

7 b. Sanhedrin. $46 a$.

8 Jacob Milgrom, The JPS Torah Commentary: Numbers (Philadelphia: Jewish Publication Society, 1990), 408.

9 b. Sanhedrein.78b

10 Sif. Num.112; Sif. Emor 14:15; b. Shab.96b.

11 Martin Noth, Numbers: A Commentary (Philadelphia: The Westminster Press, 1968), 117; Philip J. Budd, Numbers (WBC 5; Waco: Word Books Publishers, 1984), 175-176.

12 J. Weingreen, "The Case of the Woodgatherer (Numbers XV 32-36)," VT 16 (1996): 361-364.

13 A. Phillips, "The Case of the Wood Gatherer Reconsidered," VT 19 (1969):125128. 
20:10; Prov 29:24). This is consistent with passages in the ancient Near Eastern treaties in which people were required to report plots against the king. ${ }^{14}$

Another passage on stoning due to idolatry is Deut 17:2-7. Here, it is the worship of foreign gods or the sun, moon or heavenly host which is the violation of the first commandment not to worship other gods. This deviation, an import from Assyria, was prevalent in Judah during the reign of Manasseh in the seventh century B.C.E. and was denounced by the prophets of the age (Jer 7:18; 19:13; 44:17; Zeph 1:5). In this case, too, transgressors were stoned to death. ${ }^{15}$ When the crime was known "and you have been informed or have learned about it"( Deut 17:4), the official duty was to investigate it thoroughly. This was done with the testimony of two or more witnesses, in order to protect against dishonest or mistaken testimony. The "two or more" shows that two are the minimum but not the maximum. The witnesses were the first who started the stoning which was followed by the rest of the people.

Those who blaspheme and pronounce the divine name, whether nativeborn or foreign, are to be stoned (Lev 24:16). The death penalty is stressed three times, twice with "he is to be put to death" and once by "to stone." the previous verse - "whoever curses his God shall bear his sin" — which does not specify a punishment. Consequently, some of the sages understood that a person was not liable for the death penalty unless he or she uttered the ineffable name; but R.Meir wrote that this refers specifically to the Tetragrammaton. ${ }^{17}$ It seems likely that the blasphemer, too, was to be stoned to death: "Take the blasphemer outside the camp... and let the whole community stone him" (Lev 24:14).

The man in question was punished because of the action reported in verse 11: "וֹ וٕنקב the Name and cursed." The meaning of the verb here has been a matter of dispute at least since Talmudic times. ${ }^{18}$ Ibn Ezra offers two interpretations: first, that it derives from the root נקב 'utter, speak,' as in "a new name that the mouth of the Lord will utter (Isa 62:2); or, in the nif'al, "Moses and Aaron took those men, who were designated (ניקריבוּ ) by name" (Num 1:17). His second interpretation is that it comes from the root ('curse'), as in the story of Balaam: "How can I curse ( Ibn Ezra prefers the first derivation, namely, that the man first uttered the Divine

14 Jeffry H. Tigay, The JPS Torah Commentary: Deuteronomy (Philadelphia: The Jewish Publication Society, 1996), 132; M. Weinfeld, Deuteronomy and the Deuteronomic School (Oxford: Oxford University Press,1970), 94-96.

15 The death penalty for idolatry is also stipulated in Exodus (again without specification of the method): "Whoever sacrifices to a god other than the Lord alone shall be proscribed" (Exod 22:19 [20]).

16 John E. Hartley, Leviticus (WBC 4; Dallas: Word Books Publishers, 1992), 410.

17 b. Sanhedrin 56a.

18 Ibid. 
name and then cursed. Rashi, by contrast, believes that verses $15-16$ refer to a single sin of intentional blasphemy. When the text specifies that "whoever curses his God shall bear his sin," the meaning is evidently that he will be stoned to death, as stated inverse 14 and can be derived a fortiori from verse 16: if a person who utters the Divine name is to be put to death, a fortiori someone who utters the Divine name and also curses God merits the same punishment.

The punishment of stoning for blasphemy is also part of the story of Naboth the Jezreelite, who owned a vineyard that King Ahab coveted. When Naboth refused to sell the vineyard or accept another plot in exchange for it because it was his ancestral patrimony, Ahab's wife Jezebel accused Naboth of cursing God and the king. Naboth was tried, found guilty and stoned to death (1 Kgs 21:13). According to another tradition, Naboth's sons also were executed (2 Kgs 9:26).

Blasphemy is prohibited as well in the Book of the Covenant (Exod 22:27), which admonishes every person against cursing and showing disrespect to their superiors - specifically, God and the rulers of the people (cursing one's parents is the subject of a separate prohibition [21:17; cf. Lev 20:9]). The reference here to the chieftain, sưָׁׁיא, suggests that this is an ancient law rooted in the tribal period. Later, under the monarchy, the standard idiom is "God and king" (1 Kgs 21:10 [or "king and god"; Isa 8:21]). That cursing the Lord is a capital offence can also be inferred from the utterance of Job's wife, who urges him to "curse God, and die" (Job 2:9).

Stoning is also the penalty for one who dedicates (lit. gives) his children to Molech (Lev 20:2). At first, the verse states only that he must be put to death (מוֹת (מוּת). The hof'al indicates that the reference is to death by human agency,that is, execution. The second part of the verse specifies the form of execution, namely, that the people stone him. ${ }^{19}$ According to the medieval exegete Joseph Bekhor-Shor, his transgression is double, involving idolatry and murder. The Molech cult is tantamount to murder because the child offered as a sacrifice is burned to death (Ps 106:38).

Verse 3 states that, in addition to being stoned to death, the transgressor will suffer excision. The cult of Molech defiles the Sanctuary, whether by introducing ritual objects into it or placing them near it. It profanes the Divine name, as a consequence of a false oath as well as through the improper sacrifice, neglect of purity and practice of idolatry. In later literature, we encounter the חתילוּל הָשָׁם 'desecration of the Divine name' with reference to actions that bring disrepute to the Israelites or the Torah. ${ }^{20}$ The punishment of excision

19 J. Milgrom, Studies in Levitical Terminology (Vol. 1; Berkley: University of California Press, 1970), 5.

20 Baruch Levine, Leviticus (The JPS Torah Commentary; Philadelphia: The Jewish Publication Society, 1989), 128; Mish. Avot.4:4, 5:9. 
mentioned here affects the malefactor's family, too. According to the Sifra and Talmud, this is because the family will always attempt to protect its father. ${ }^{21} \mathrm{We}$ should remember that the patriarchal family followed the father in ritual matters. Another possibility is that the penalty extended beyond the immediate transgressor because he sacrificed his son to Molech with his family's knowledge.

Another transgression to be punished by stoning is that of "a man or a woman who has a ghost or a familiar spirit" (Lev 20:27). The location of this verse, at the very end of the chapter, is unexpected. Levine conjectures that it was inserted there because the punishment for having a ghost or familiar spirit is not mentioned in verse 6: "If any person turns to ghosts and familiar spirits and goes astray after them, I will set My face against that person and cut him off from among his people." He notes that verses 2-4, which deal with a similar transgression, do make death by stoning explicit; perhaps, then, verse 6 is an abridged text. ${ }^{22}$ On the other hand, Daube, who studied ancient Roman law, notes that the Latin legislator, too, presented this law at the end of the code rather than in the expected place. ${ }^{23}$ More plausible, however, is Ibn Ezra's explanation that verse 6 deals with calling up a ghost in private, without witnesses; hence, the punishment is one meted out by God-excision. By contrast, verse 26 deals with a public séance, which is actionable by the court and for which the penalty is death by stoning. Another possible explanation for the presence of two separate laws is that the original chapter comprised only verses 7-26 while verses 1-6 and 26 were added later, and verse 27 , lastly.

\section{STONING AS PUNISHMENT FOR SOCIAL TRANSGRESSIONS}

Stoning is also the penalty for some anti-social crimes. For example, it is the fate prescribed for the wayward and defiant son (Deut 21:18-21), whose actions are accounted a capital offence in order to emphasise the gravity of disrespect for parents. R. Yosé explains that the wayward and defiant son is punished for his anticipated future - when he grows up and has no money to satisfy his appetites he will become a thief. ${ }^{24}$ To defend society against incorrigible criminals, the Torah prescribes the death penalty for him, in order to "purge the evil from your midst" (v. 21). The idea is that it is better for one person to die than many. Defiance of parental authority is also mentioned in the Sumerian family laws of the Old Babylonian period (nineteenth century B.C.E.): "If a son says to his father, 'you are not my father,' he (the father) may shave him, may put the slave

21 b. Shevuot. $39 a$.

22 Levine, Leviticus, 137.

23 D. Daube, "Codes and Codas in the Pentateuch," Juridical Review 53 (1941): 242261.

24 M. Sanh.8:5 
mark on him and sell him." 25 Moreover, "if a son says to his mother, "you are not my mother,' they shall shave half his head, lead him around the city, and put him out of the house."26

In the biblical tradition, severe disrespect for one's parents is grounds for death by stoning; honouring them is rewarded by long life. Biblical law deprives the father of his independent authority to punish his son with death; that belongs to the public judicial domain overseen by the elders. In addition, the father's accusation must be seconded by the mother, so as to prevent a situation in which a father tries to keep his first-born son by an unloved wife from inheriting a double share of his estate. ${ }^{27}$ The juxtaposition of the passage about the wayward and defiant son with that about the sons of the loved and unloved wives can also be understood in light of the parallel in the Laws of Hammurabi:

168: If a seignior, having made up his mind to disinherit his son, has said to the judges, "I wish to disinherit my son," the judges shall investigate his record, and if the son did not incur wrong grave (enough) to be disinherited, the father may not disinherit his son.

169: If he has incurred wrong against his father grave (enough) to be disinherited, they shall let him off the first time; if he has incurred grave wrong a second time, the father may disinherit his son. ${ }^{28}$

In Mesopotamia, thus, disrespect to one's parents led to disinheritance or being sold into slavery whereas in Israel it was a capital offence in extreme cases such as cursing of or striking parents.

The Hebrew Bible requires the parents to hand over their son to the elders, who, after thorough investigation, decide his fate. The Torah transferred this authority from the father to the elders because the latter would not reach a hasty verdict, unlike an angry father. All the inhabitants of the town took part in the execution of the sentence. Although the general rule was that the principal accuser threw the first stone, here, the parents are not said to participatebecause of the sensitivity of the matter but also perhaps to indicate that parents do not have the power of life and death over their children. The Sages were of the opinion that this law had never been implemented and appears in the Torah only for the sake of instruction and edification. According to the Talmud, "It never happened and never will happen. Why then was this law written? — That

25 David Marcus, "Juvenile Delinquency in the Bible and the Ancient Near East," JANESCU 13 (1981): 39.

26 Ibid.

27 A.H. Freimann, “Ben sorrer u-moreh,” Entsiqlopedia Miqrait 2 (1950-1982): $161-162$.

28 "The Code of Hammurabi" (trans. Theophile J. Meek; ANET nos. 168, 169), 173. 
you may study it and receive reward." However, Rabbi Jonathan disagreed, saying, "I saw him and sat on his grave."29

Stoning seems to have been the standard form of judicial execution. It applied, for instance, to an adulterous woman. If a husband alleged that his wife was not a virgin when they got married and his charges were proven, she was to be stoned at the door of her father's house (Deut 22:21). ${ }^{30}$ An interesting parallel is found in the Code of Hammurabi: "If a seignior made a breach in a house, they shall put him to death in front of that breach and wall him in." ${ }^{31}$ Executing the daughter at the entrance of her father's house came to express the communal condemnation of the father who failed to educate his daughter. ${ }^{32}$

If a virgin who was not betrothed is raped, she is not to be punished for the loss of her virginity (vv. 28-29). The rapist, too, suffers a less severe punishment than one who rapes a betrothed virgin because he has not impaired the legal bond, which is considered to be tantamount to marriage between the woman and her fiancé. In this situation, the Torah's goal is to protect the victim and her father. The young woman's prospects of marriage have been destroyed by the loss of her virginity; the father has lost the bride-price he expected to receive when she married. Consequently, the rapist must pay the father an amount equal to the bride price. He must also marry his victim and may never divorce her.

Under the law code we are considering here, a virgin who lost her virginity before marriage is to be executed (v. 21). Perhaps she is deemed to have been promiscuous after her betrothal and her situation is equivalent to that of adultery by a betrothed virgin (vv. 23-24). Alternately, this harsh punishment is meted out to her because she deceived her future husband, who discovered the truth only after their marriage. Her loose behavior while still in her father's house and under his authority renders her culpable - a severe offence against her father, just as adultery by a married woman, is a severe offence against her husband.

Another case is that of a betrothed virgin found lying with a man in the city (Deut 22:23-24). Since the act took place in an inhabited area, she is assumed to have been a willing participant. Both the man and woman were to be taken to the city gate and stoned to death - the woman, because she did not resist and the man, for having intercourse with another man's affianced wife (v. 24).

29 b. Sanhedrin. $71 a$.

30 For accusations of adultery in the Code of Hammurabi, see "ANET nos. 131, 132," 171.

31 "The Code of Hammurabi," ANET no. 21, 167.

32 A. Phillips, "Another Look at Adultery," JSOT 20 (1981): 10; Duane L. Christensen, Deuteronomy 21:10-34:12 (WBC 6b; Nashville: Thomas Nelson, 2002), 521. 
In this case, they are equal partners in a transgression that is both ritual and criminal.

In the Code of Hammurabi as well as in the Middle Assyrian Laws (unlike the Hebrew Bible), a husband has the right to forgive an adulterous wife and stipulate the punishment for her and her partner. According to the Code of Hammurabi,

If the wife of a seignior has been caught while laying with another man, they shall bind them and throw them into the water. If the husband of the woman wishes to spare his wife, then the king in turn may spare his subject. $^{33}$

\section{Under the Middle Assyrian Laws,}

If a seignior has caught a (nother) seignior with his wife, when they have prosecuted him (and) convicted him, they shall put both of them to death, with no liability attaching to him. If, upon catching (him), he has brought him either into the presence of the king or into the presence of the judges, when they have prosecuted him (and) convicted him, if the woman's husband puts his wife to death, he shall also put the seignior to death, but if he cuts off his wife's nose, he shall turn the seignior into a eunuch and they shall mutilate his whole face. However, if he let his wife go free, they shall let the seignior go free. ${ }^{34}$

Nevertheless, there may be an echo in the biblical text of the idea of allowing the husband to decide the fate of an adulterous wife: "The fury of the husband will be passionate; He will show no pity on his day of vengeance. He will not have regard for any ransom; He will refuse your bribe, however great" (Prov 6:34$35)$. In other words, the husband could have forgiven his wife but did not do so. A similar situation is reflected in the historical case of David and Bathsheba (2 Sam 11), as well as in Jer 3:8 and Hos 4:5. Perhaps an adulterous wife was originally punished by divorce only and the death penalty was a later development.

On the other hand, Deut 22:25-27 refers to a betrothed woman discovered lying with a man in the field. In this case, only the man is to be executed. She is not culpable because, in the open countryside, even if she had called out, no one would have heard her. She is given the benefit of the doubt and it is assumed that she did cry out. How the man should be executed is not stated here but it seems likely that it was by stoning. ${ }^{35}$ In the Assyrian Law, too, we find that the woman's resistance is taken as an indication of her innocence:

\footnotetext{
33 "The Code of Hammurabi," ANET no. 129, 171.

34 "The Middle Assyrian Laws," (trans. Theophile J. Meek; ANET no. 15), 181.

35 On adultery outside the Bible, see J.J. Finkelstein, "Sex Offenses in Sumerian Laws," JAOS 86 (1966): 355-372.
} 
If, as a seignior's wife passed along the street, a (nother) seignior has seized her, saying to her, "Let me lie with you," since she would not consent (and) kept defending herself, but he has taken her by force (and) lain with her, whether they found him on the seignior's wife or witnesses have charged him that he lay with the woman, they shall put the seignior to death, with no blame attaching to the woman. ${ }^{36}$

\section{THE PROCEDURE}

Stoning was carried out in public. The stones were cast by the "people of the land" (Lev 20:2), which here connotes all Israelites and not a particular institution or agency, as is shown by the parallels, "all the congregation" (Lev 24:16, Num 15:35); "all the men of his city" (Deut 21:21).

Two roots- סקל - are employed to express death by stoning but there does not seem to be any significant difference between them. ${ }^{37}$ The verb רִ רִג indicates how the stone was used, namely, that it was hurled or launched by a slingshot. ${ }^{38}$

The entire community was obligated to participate in stoning because those who stoned the condemned person were thereby purifying themselves of the guilt that the malefactor had imposed on the community. This is indicated by Lev 24:14, where we are told that those who had heard the man blaspheme were to lay their hands on his head-perhaps as method of positive identification before his execution. Placing one's hands on the head of another generally signified a transfer of authority but it may also have ritual and legal significance, as in this verse. ${ }^{39}$ When the stoning was ordered by a court of law, the witnesses hurled the first stone (Deut 17:7), followed by the rest of the people. ${ }^{40}$ In other words, the witnesses are responsible for the execution, and if their testimony was false, they are murderers. The Mishnah records the warning given to witnesses in capital cases:

Know that capital cases are unlike monetary cases: in monetary cases a witness may pay money and make atonement but in capital cases the

36 "The Middle Assyrian Laws," ANET no. 12, 181.

37 D.H. Livingston, "The Crime of Leviticus xxiv 11," VT 36 (1986): 353.

38 Leviticus 24:14; Num 15:35-36; 21:21.

39 David Daube, The New Testament and Rabbinic Judaism (London: Athlone Press, 1956), 227; D. Wright, "The Gesture of Hand Placement in the Hebrew Bible and in Hittite Literature," JAOS 106 (1986): 433-446. In Hittite sources, we read about the Ritual of Tunnawi in which a women touched the horn of a fertile cow in the hopes of transferring the animal's fertility to herself. See Albrecht Goetze, The Hittite Ritual of Tunnawi (AOS 14; New Haven: American Oriental Society, 1938), 21 n. 34.

40 According to M. Sanhedrin 45a, this law applied to all of those who were stoned even though it is stated only about the idolator (Deut 17:7) and one who incites to idolatry. In the latter case, the first stone was to be hurled by the person who was incited (Deut 13:10) since it is logical that that was also a witness at the trial. 
witness is answerable for the blood of him [who is wrongfully condemned] and for the blood of his posterity. ${ }^{41}$

Stoning took place outside the camp. This was done to ensure that the camp which was a holy place, is not contaminated by death (1 Kgs 21:13). Contact with a dead body is absolutely forbidden; anyone who touches a corpse is ritually unclean for seven days (Num 19:1-22). According to the laws relating to the impurity of the dead, "when a person dies in a tent, whoever enters the tent and whoever is in the tent shall be unclean seven days" (Num 19:14). That is, anyone who enters the tent where the corpse is laid as well as the major appurtenances of daily life — clothes, mattresses, pots and jugs - is defiled, even if the person does not come into direct contact with the dead body. The impurity of death is the most extreme form of defilement (Lev 5:2;6:9;9:6-7). In the ancient world, human beings believed that corpses were impure and must be avoided. This taboo was motivated by the fear of death and especially the spirit of the dead. Louis Finkelstein argues however that the whole matter of ritual impurity was related to hygiene. In the hot climate of the Middle East, a corpse was a ready source of disease and epidemics. Such laws were of special importance in connection with festivals held in the Temple, which attracted large numbers of people. Hence, the laws of purity and impurity "were rules of health which alone prevented each festival from leading to an epidemic." 42 The problem with this explanation is the halakhic rule that if a majority of the people is impure, the pilgrimage to the Temple and associated sacrifices are not postponed. ${ }^{43}$

The participation of all Israel in the act of stoning came to serve as a warning to others — "Thus all Israel will hear and be afraid, and such evil things will not be done again in your midst" (Deut 13:12). We should note that in the book of Deuteronomy where stoning is mentioned, we find the formula "you shall purge the evil from your midst" (Deut 13:6; 17:5; 22:21, 24). ${ }^{44}$ Most of the stoning took place outside the camp with the exception of the case of an adulterous woman. If a husband alleged that his wife was not a virgin when they were married and his charges were proven, she was to be stoned at the door of her father's house. This location implies parental responsibility for the sexual behavior of their children. Before the person was stoned to death, his cloth was removed, as in Ezek 16:39, "I will deliver you into their hands, and they shall tear down your eminence and level your mounds; and they shall strip you of your clothing and take away your dazzling jewels, leaving you naked and bare." This interpretation is reinforced by a reading from the Talmud:

41 M. Sanhedrin 4:5.

42 Louis Finkelstein, The Pharisees (Philadelphia: Jewish Publication Society, 1938), 1: 27.

43 b. Pesahim 77a, 79a; b. Yoma 50b-51a.

44 Duane L. Christensen, Deuteronomy 1:1-21 (9th ed.; Nashville: Thomas Nelson, 2001), 271-272. 
When he came to four ells from the place of execution, he was stripped of his garments. If a male he was covered in front; and if a female, she was covered on both sides; So, said R. Jehudah. The sages, however, say: A male was stoned while naked, but not a female. ${ }^{45}$

This change in the Talmud about women came probably because of concern for women's modesty.

The motivation behind stoning seems to be the removal the criminal from the camp and the city. This removal was not merely physical; it also bore significance for the dead man's spirit. Following death, the text describes burial with קבר (bury) is common to all Semitic languages. Death and burial often appear together; thus, we find consecutive forms: "he died... and was buried." In addition, the name of the subject and the place of burial were common: "And Abraham breathed his last, dying... His sons Isaac and Ishmael buried him in the cave of Machpelah" (Gen 25:8). The burial act was done by the son who carried the line of the family who received the blessing. It was believed that a man was reunited with his ancestors. This is expressed in the Hebrew Bible by idioms such as "lie down with one's father" (Gen 47:30; Deut 31:16; 2 Sam 7:12; used 35 times in 1 and $2 \mathrm{Kgs}$ and 2 Chron). In all the cases that involved the punishment by stoning to death, there is no single description of burial, what we find is that the person was stoned to death. We believe that it is not a coincidence that the people who were stoned to death were left unburied. The ancients believed that a person left unburied could not rejoin his ancestors. The punishment of stoning prevented the burial of the corpse since the broken fragments of the body were left to be eaten by the birds and beasts. This is clearly attested in the case of Naboth. After the testimony of the two scoundrels, Naboth was stoned to death. Subsequently, God sent Elijah to Ahab with a message: "Thus said the Lord: In the very place where dogs lapped up Naboth's blood, the dogs will lap up your blood too" (1 Kgs 21:19). At the meeting between Elijah and Ahab, Elijah further told him: "All of Ahab's line who die in the town shall be devoured by dogs, and all who die in the open country shall be devoured by the birds of the sky" (v. 24). A person whose body was eaten by wild beasts could not join his ancestors because he was in the intestines of the animals. His spirit suffered torment because it could not be reunited with his ancestors. This is also the sense of the punishment of excision in which "that soul [is] cut off from among his people" (Exod 31:14 et passim). Note that many of the crimes punishable by excision may also make the criminal liable to being stoned to death.

\section{E NON-BURIAL}

Non-burial was also a curse. In the war of words between David and Goliath, the Philistine curses David and promises: "I will give your flesh to the birds of the

45 b. Sanhedrin. 6:3 
sky and the beasts of the field" (1 Sam 17:44). Not to be outdone, David counters with the words, "I will strike you down, and cut off your head; and I will give the carcasses of the Philistine camp to the birds of the sky and the beasts of the earth" (v. 46). Again, the curse here is not being buried so that the spirit wanders aimlessly. The curse of non-burial is also found in the prophetic literature, as in "The carcasses of this people shall be food for the birds of the sky and the beasts of the earth, with none to frighten them off' (Jer 7:33), an echo of Deut 28:26. That there are none to frighten off the scavengers implies that there are no survivors or that no one pities them. Similarly we read,

They shall die of deadly diseases. They shall not be lamented, nor shall they be buried; they shall be as dung on the surface of the ground. They shall perish by the sword and by famine, and their dead bodies shall be food for the birds of the air and for the beasts of the earth (Jer 16:4).

The curse of non-burial is also found in extra-biblical sources, for example, in the Vassal Treaties of Esarhaddon:

May Ninurta, leader of the gods, fell you with his fierce arrow, and fill the plain with your corpses, give your flesh to eagles and vultures to feed upon. ${ }^{46}$

Let dogs and pigs eat your flesh, and may your spirit have no one to take care of and pour libation to him. ${ }^{47}$

May the earth not receive your body for burial, may the bellies of the dogs and pigs be your burial place. ${ }^{48}$

Clearly victorious kings treated their vanquished enemies savagely. The annals of Ashurbanipal report what he did to his foes: "I fed their corpses cut into small pieces, to dogs, pigs, zibu-birds, vultures, the birds of the sky and (also) to the fish of the ocean." ${ }^{49}$ In the Epic of Gilgamesh, after Enkidu returns from the underworld, he is asked, "Him whose corpse was cast out upon the steppe hast thou seen?" He replies, "I have seen: His spirit finds no rest in the netherworld." 50

\section{F A POSTHUMOUS CONCEPT}

At a later period, the procedure for stoning was modified, as we find in the Mishnah:

The place of stoning was twice the height of a man. One of the witnesses knocked him down by the hips; if he turned over on his heart the witness turned him over again on his back. If he

\footnotetext{
46 “The Vassal-Treaties of Esarhaddon” (trans. Erica Reiner, ANET 538 no. 41).

47 Ibid., no. 47.

48 Ibid., 539 no. 56.

49 "The Death of Sennacherib" (trans. A. Leo Oppenheim; ANET 288), 65-82.

50 "The Epic of Gilgamesh" (trans. E.A. Speiser; ANET 99, xii), 152-154.
} 
straightaway died that sufficed; but if not, the second witness took the stone and dropped it on his chest. If he straightaway died that sufficed; but if not, he was stoned by all Israel. ${ }^{51}$

According to Rashi, the stoning place must not be too high; to prevent horrible mutilation of the body; but neither should it be too low, so that death could be immediate. The change was evidently motivated by a desire to preserve the condemned man's corpse. The Talmudic sages may have been influenced by the story in 2 Chron 25:12, which recounts that Amaziah had the Edomite captives hurled from the Rock of Sela. They may also have been influenced by Roman, Syrian or Greek law. ${ }^{52}$

A comparison of judicial execution forms mentioned in the Hebrew Bible with those in the Talmud indicates that the latter made an effort to preserve the body of an executed man. ${ }^{53}$ The difference may stem from the fact that in Talmudic times the idea of resurrection was well developed. Even though the idea of the resurrection of the dead was not fully developed in the biblical literature, we find some hints about it (Deut 32:9; Isa 26:19; Dan 12:2-3; Hos $6: 1-2)$. The notion that the righteous and the wicked shared the same fate and are both found in Sheol was too simplistic. In the Hebrew Bible, we read that the underworld is a void; the dead cannot praise the Lord and do not know anything about the living. The belief in the underworld as the final station of life, from which there is no return and which is utterly divorced from reward and punishment, came to represent too naive and too cruel a notion. It left no room for answering the thorny question of why evildoers prosper and the righteous suffer. Hence, the biblical texts began asking questions about the underworld and the survival of the soul. As Qoheleth wondered: "Both go to the same place; both came from dust and both return to dust. Who knows if a man's life-breath does rise upward and if a beast's breath does sink down into the earth?" (Eccl 3:2021). This same book of Ecclesiastes, evidently written between 500 BCE and $100 \mathrm{CE}$, concludes: "And the dust returns to the ground as it was, and the lifebreath returns to God Who bestowed it" (Eccl 12:7). This clearly reflects a belief in the immortality of the soul.

Pagans in the ancient world feared that the manner of death could influence whether or not a man resurrected. As late as the tenth century, the Jewish masses held similar views. ${ }^{54}$ According to Saul Lieberman, medieval

51 M. Sanhedrin. 6:4.

52 Throwing from a rock as punishment is mentioned in The Twelve Tables 8:15 "that slaves caught in the act of theft be whipped with scourges and be thrown from the rock." See Paul Robinson Coleman-Norton, The Twelve Tables (rev. ed.; Princeton: Princeton University, 1952), fn.48; 2 Macc 6:10.

53 b. Sanhedrin. 45a, 52a; b. Pesahim 75a; b. Ketubot $37 b$.

54 Saul Lieberman, "Some Aspects of After Life in Early Rabbinic Literature," in Harry Austryn Wolfson Jubilee Volume (vol. 2, no 112; Jerusalem: American Academy 
literature showed that non-burial was a bad omen for the deceased and a severe punishment, indicating that the man was a sinner. ${ }^{55}$ Evidently the different modes of unnatural death which include the punishment of stoning in the Hebrew Bible as well as the different modes of death that appear in the Talmud point to a posthumous concept. ${ }^{56}$ The punishment continued after death. In other words, the punishment of stoning in the Hebrew Bible meant an end to continuity and the final extinction of the deceased, who would not be "gathered to his ancestors." His spirit wandered aimlessly never to be resurrected.

\section{G CONCLUSION}

In conclusion, execution by stoning took place outside the camp or outside the city in order to avoid the impurity caused by contact with a dead person. When the stoning was ordered by a court of law, the witnesses hurled the first stone (Deut 17:7), followed by the rest of the people. The entire community was obligated to participate in stoning because those who stoned the condemned person were thereby purifying themselves of the guilt that the malefactor had imposed on the community. Stoning is in the domain of human relations with God; therefore, we find violation of the Sabbath, worship of other gods or incitement to do so, blasphemy and divination by spirits leading to stoning. Stoning is also found to be the punishment for social transgressions includings the wayward and defiant son, adulterous woman and betrothed virgin found lying with a man in the city, where both the man and woman were stoned to death. Death and burial often appear together but not in the case of stoning. There is no description of what was done to the bodies of people who were stoned to death; more than likely, they were left unburied in the field. We must remember not much was left after the whole community participated in this act. Non-burial was worse than death because the spirit of the dead could not find rest and would never reach the underworld, therefore, it was considered a curse. Later, according to the Talmud, an effort was made to preserve the body of the executed man to prevent horrible mutilation of the body. This difference between the biblical text and the Talmudic text stems from the fact that in the Talmud the idea of resurrection was well developed, thus, preservation of the body for resurrection was important.

for Jewish Research, 1965),528; M. Stein, "Mother Earth in Old Hebrew Literature," Tarbiz 9 (1938): 272-274 (Hebrew).

55 He goes on to say, however, that the Sages also believed that the premature death of a normal sinner and non-burial served as atonement and helped the man acquire his share of the world to come. According to Lieberman, the Christians adopted a similar tradition; in the late Middle Ages some requested that their bodies be thrown into the fields or a river, like the carcasses of animals; but such abuse is contrary to the spirit of Judaism. See $b$. Sanhedrin $46 b$ and 104a; Lieberman, "After Life in Early Rabbinic Literature," 530.

56 b. Berakhot 8a; b. Baba Bathra $17 a$. 


\section{H BIBLIOGRAPHY}

Budd, Philip J. Numbers. World Bible Commentary 5. Waco: Word Books, 1984.

Christensen, Duane L. Deuteronomy 21:10-34:12. World Bible Commentary 6b. Nashville: Thomas Nelson, 2002.

Deuteronomy 1:1-21: 9. Revised edition. Nashville: Thomas Nelson, 2001.

Daube D. "Codes and Codas in the Pentateuch." Juridical Review 53 (1941): 242-261. The New Testament and Rabbinic Judaism. London: Athlone Press, 1956.

Finkelstein J.J. "Sex Offenses in Sumerian Laws." Journal of the American Oriental Society 86 (1966): 355-372.

Finkelstein, Louis. The Pharisees. Philadelphia: Jewish Publication Society, 1938.

Freimann, A.H. “Ben sorrer u-moreh.” Entsiqlopedia Miqrait 2 (1950-1982):161-62.

Goetze, Albrecht. The Hittite Ritual of Tunnawi. American Oriental Series 14. New Haven: American Oriental Society, 1938.

Hartley, John. E. Leviticus. World Bible Commentary 4. Dallas: Word Books, 1992.

Levine Baruch A. Leviticus. The JPS Torah Commentary Philadelphia: The Jewish Publication Society, 1989.

Lieberman Saul. "Some Aspects of After Life in Early Rabbinic Literature." Pages 495-532 in Harry Austryn Wolfson Jubilee Volume. Volume 2. Edited by Harry Austryn Wolfson and Saul Lieberman. Jerusalem: American Academy for Jewish Research, 1965.

Livingston, D.H. "The Crime of Leviticus xxiv 11." Vetus Testamentum 36 (1986): 352-354.

Marcus David. "Juvenile Delinquency in the Bible and the Ancient Near East." Journal of the Ancient Near Eastern Society of Columbia University 13 (1981): 31-62.

Meek, Theophile J., trans. "The Code of Hammurabi." Pages 163-180 in Ancient Near East Texts Relating to the Old Testament. 3rd edition. Edited by James B. Pritchard. Princeton: Princeton University Press, 1969.

"The Middle Assyrian Laws." Pages 180-188 in Ancient Near East Texts Relating to the Old Testament. 3rd edition. Edited by James B. Pritchard. Princeton: Princeton University Press, 1969.

Milgrom, Jacob. The JPS Torah Commentary: Numbers. Philadelphia: Jewish Publication Society, 1990.

. Studies in Levitical Terminology. Vol. 1. Berkley: University of California Press, 1970.

Noth, Martin. Numbers: A Commentary. Philadelphia: The Westminster Press, 1968.

Oppenheim, A. Leo, trans. "The Death of Sannacherib." Page 288 in Ancient Near East Texts Relating to the Old Testament. 3rd edition. Edited by James B. Pritchard. Princeton: Princeton University Press, 1969.

Phillips, A. "The Case of the Wood Gatherer Reconsidered." Vetus Testamentum 19 (1969): 125-128.

"Another Look at Adultery." Journal for the Study of the Old Testament 20 (1981): 3-25.

Pritchard, James B., ed. Ancient Near East Texts Relating to the Old Testament. 3rd edition. Princeton: Princeton University Press, 1969.

Reiner, Erica, trans. "The Vassal-treaties of Esarhaddon." Pages 534-541 in Ancient Near East Texts Relating to the Old Testament. 3rd edition. Edited by James B. Pritchard. Princeton: Princeton University Press, 1969. 
Robinson Paul Coleman-Norton. The Tweleve Tables. Revised edition. Princeton: Princeton University, 1952.

Speiser, E.A., trans. "The Epic of Gilgamesh.” Pages 72-99 in Ancient Near East Texts Relating to the Old Testament. 3rd edition. Edited by James B. Pritchard. Princeton: Princeton University Press, 1969.

Stein, M. "Mother Earth in Old Hebrew Literature." Tarbiz 9 (1938): 257-277.

Tigay, Jeffry H. Deuteronomy. The JPS Torah Commentary Philadelphia: The Jewish Publication Society, 1996.

Weinfeld, M. Deuteronomy and the Deuteronomic School. Oxford: Oxford University Press, 1972.

Weingreen, J. "The Case of the Woodgatherer (Numbers XV 32-36)." Vetus Testamentum 16 (1996): 361-364.

Wright D. "The Gesture of Hand Placement in the Hebrew Bible and in Hittite Literature." Journal of the American Oriental Society 106 (1986): 433-446.

Dr. Shaul Bar, Bornblum Judaic Studies, University of Memphis; Memphis, TN. Email: sbar@memphis.ed, ORCID: https://orcid.org/0000-0003-1186-1925. 